\begin{tabular}{llllllll}
\hline $\mathrm{A}$ & $\mathrm{R}$ & $\mathrm{T}$ & $\mathrm{Y}$ & $\mathrm{K}$ & $\mathrm{U}$ & $\mathrm{E}$ & $\mathrm{Y}$
\end{tabular}

PIOTR GUZOWSKI

RADOSEAW PONIAT

Instytut Historii i Nauk Politycznych, Uniwersytet w Białymstoku

\title{
STANDARDY I JAKOŚĆ ŻYCIA W HISTORIOGRAFII ŚWIATOWEJ. PRZEGLĄD BADAŃ I PROBLEMÓW
}

Zarys treści: Autorzy opisują historię badań nad standardami życia w przeszłości oraz wskazują na różnicę między nimi a studiami nad jakością życia. Artykuł zawiera też przegląd metod badań nad standardami, skupiając się na najważniejszych z nich, dotyczacych takich zagadnień, jak konsumpcja, płace realne i obliczenia PKB per capita, biologiczny standard życia, wskaźniki demograficzne (oczekiwana długości życia, umieralność noworodków i niemowląt), nierówności ekonomiczne, alfabetyzacja i umiejętność liczenia.

The content outline: The authors of the paper describe the history of the research of standards of living in the past and indicate the difference between this branch of research and the study of the quality of life. The paper contains an overview of the methodology of the study of standards, focusing on the most important sources, such as consumption, real wages and calculations of GDP per capita, biological standard of living, demographic indices (expected lifespan, newborn and infant mortality rate), economic inequalities, literacy and numeracy.

Słowa kluczowe: standardy życia, jakość życia, konsumpcja, płace realne, PKB per capita, biologiczny standard życia, alfabetyzacja, numeracy, nierówności

Keywords: standards of living, quality of life, consumption, real wages, GDP per capita, biological standard of living, literacy, numeracy, inequalities

Badania dotyczące standardów i jakości życia mają w nauce już długą tradycję. Należy tu też od razu podkreślić, że prowadzone są one nie tylko przez historyków. Istotną rolę odgrywają tu ekonomiści, demografowie, socjologowie, antropologowie fizyczni czy psychologowie 
społeczni, pytający od dawna o przyczyny rozwoju, a w kontekście historycznym - o regiony, które doświadczały największych sukcesów gospodarczych $\mathrm{w}$ kolejnych epokach, począwszy od starożytności. To właśnie w ich pracach sformułowana została większość teorii i koncepcji wykorzystywanych $\mathrm{w}$ omawianych tu badaniach, opracowane też zostały metody, które historycy próbuja z lepszym lub gorszym skutkiem wykorzystywać we własnych analizach ${ }^{1}$. Co zreszta charakterystyczne, badacze przeszłości piszący na temat standardów życia bardzo rzadko definiuja to pojęcie, zakładając zapewne, że jest ono w sumie oczywiste i przez czytelników zrozumiałe. Postępowanie takie można po części zrozumieć, skoro takie terminy, jak PKB czy HDI sa już od dawna wykorzystywane poza akademią i często natknąc się na nie można nawet w popularnych publikacjach prasowych. Gdy w literaturze historycznej pojawiaja się mimo wszystko próby bardziej formalnego określenia standardu życia, szybko okazuje się, że powiązanie definicji wypracowanej na polu współczesnej ekonomii z tym, co historycy moga $w$ praktyce zbadać, jest zadaniem trudnym. Jak bowiem określić „całkowitą użyteczność, jaką jednostka czerpie z konsumpcji dóbr uzyskanych w wyniku pracy, inwestycji i transferów" w odniesieniu do populacji historycznych? W praktyce, skoro nie możemy dokładnie opisać użyteczności dóbr, uzależnionej w znacznym stopniu od postaw i zachowań występujacych w danej społeczności, uwagę koncentrować musimy na samych dobrach i możliwości ich pozyskania, a nie użyteczności². W konsekwencji więc historycy mało czasu poświęcaja na teoretyczne uzasadnienie swych analiz, woląc zawierzyć ekonomistom, demografom i socjologom. Zamiast tego podejmuja próby jak najlepszego opracowania dostępnych materiałów źródłowych i uzyskania na ich podstawie wskaźników podobnych do tych wykorzystywanych przez badaczy współczesności.

Wydaje się, że pierwszym wielkim problemem historycznym, do zbadania którego w szerokim stopniu użyto wskaźników standardu i jakości życia była analiza społecznych konsekwencji rewolucji przemysłowej. Dyskusja na ten temat, trwająca co najmniej od czasu ukazania się

1 A. Sen, The Standard of Living. The Tanner Lectures on Human Values, Clare Hall, Cambridge, 1985, red. G. Hawthorn, Cambridge 1987.

${ }^{2}$ Pełniejszy opis wielu definicji standardu życia oraz ich odniesienia do badań historycznych odnaleźć można w tekście T. Bengtssona, Living standards and economic stress, w: Life Under Pressure: Mortality and Living Standards in Europe and Asia, 1700-1900, red. T. Bengtsson et al., Cambridge 2004, s. 27-59. Tam też znajduje się podana definicja, w wersji oryginalnej brzmiąca: „the total utility a person derives from consuming a set of goods as a result of labor, investments, or transfers”. 
Położenia klasy robotniczej $w$ Anglii ${ }^{3}$, inspirowała kolejne pokolenia ekonomistów, demografów i historyków do opracowania metod pomiaru i porównywania warunków życia. Nawet wówczas, gdy wraz z upływem czasu debata ta przestała pełnić funkcję powiązanej z polityką diagnozy społecznej, wciąż budziła zainteresowanie badaczy, którzy poszukiwali $\mathrm{w}$ niej odpowiedzi na pytanie o społeczne koszty modernizacji ${ }^{4}$. W ten sposób sama rewolucja przemysłowa reprezentowała w niej liczna kategorię transformacji społeczno-ekonomicznych, jakim przez stulecia poddawane były społeczności ludzkie ${ }^{5}$. Wśród zaangażowanych $\mathrm{w}$ debatę dotycząca skutków industrializacji historyków można wydzielić kilka grup. Pomijając dość oczywiste rozróżnienie na „pesymistów” i „optymistów", szczególne znaczenie ma tu zwłaszcza podział na badaczy „ilościowych” i „jakościowych”, który w znacznym stopniu przekłada się też na różnice miedzy historykami studiującymi „standardy życia” oraz ,jakość życia”. Pierwsi z nich, nawiązując do metod współczesnej ekonomii, podjęli próbę opracowania kwantytatywnych wskaźników, za pomoca których mogliby mierzyć przemiany standardów życia. W ich przekonaniu serie danych dotyczacych takich zagadnień, jak: dochody ludności, stan zdrowia czy przewidywana długość życia powinny pozwolić na obiektywne i wolne od ideologicznych założeń apriorycznych opisanie społecznych konsekwencji industrializacji.

Członkowie drugiej grupy, sięgający w swych badaniach częściej do źródeł narracyjnych, zaś z większą podejrzliwością traktujący masowe, obiektem swych analiz uczynili szeroko pojmowana jakość życia. Obok kwestii branych pod uwagę przez badaczy standardów, obejmuje ona także zagadnienia takie jak: subiektywne poczucie zadowolenia z warunków życia, dostęp do edukacji, sytuacja mieszkaniowa, wsparcie

${ }^{3}$ F. Engels, Położenie klasy robotniczej w Anglii, tłum. A. Długosz, Warszawa 1952.

${ }^{4}$ Co zresztą ciekawe, a może też charakterystyczne dla większości wielkich debat historiografii, dyskusja ta wciąż nie zakończyła się wypracowaniem przez badaczy wspólnego stanowiska. Tak jak w XIX w., osoby oceniające społeczne konsekwencje rewolucji przemysłowej nadal można z grubsza podzielić na dwa obozy: optymistów i pesymistów. Próbę podsumowania aktualnego stanu debaty odnaleźć można w artykule S. Pamuka i J.-L. van Zandena, Standards of living, w: The Cambridge Economic History of Modern Europe, red. S. Broadberry, K.H. O’Rourke, vol. 1, Cambridge 2010, s. 217-234.

${ }^{5}$ Aby oddać szeroki zakres chronologiczny toczącej się debaty, wskazać tu można chociażby na prace dotyczące konsekwencji rewolucji neolitycznej z jednej strony i skutków forsownej industrializacji ZSRR z drugiej, por. M.N. Cohen, Health and the Rise of Civilization, New Haven 1989; D.A. Filtzer, The Hazards of Urban Life in Late Stalinist Russia. Health, Hygiene, and Living Standards 1943-1953, Cambridge 2010 . 
ze strony różnorodnych instytucji społecznych, budżety czasu... Podana tu lista nie obejmuje wszystkich poruszanych w ramach tego nurtu problemów, ale już nawet ona wskazuje na szeroki zakres prowadzonych w jego obrębie badań oraz znaczenie, jakie ma w nich komponent psychologiczny. Dostrzeżenie niewątpliwej roli tego czynnika stanowi zarówno silna, jak i słabą stronę prezentowanej perspektywy. Jego uwzględnienie $\mathrm{w}$ badaniach pozwala na znacznie szersze i pełniejsze opisanie życia codziennego historycznych społeczeństw, zwłaszcza tych jego grup, które pozostawiły po sobie odpowiednie źródła ${ }^{6}$, ale równocześnie prowadzić może do zarzutu nieobiektywności uzyskanych rezultatów. Poważne problemy sprawia też porównywanie uzyskanych wyników między regionami i okresami. Sytuacji takiej trudno się zreszta dziwić, skoro znaczna część tych analiz opiera się na bardzo zróżnicowanym materiale, często o dość incydentalnym pochodzeniu, który nie zawsze może być poddany analizie statystycznej ${ }^{7}$.

Mając świadomość istnienia szerokiej i wielodyscyplinarnej literatury poświęconej studiom nad standardami i jakością życia, w niniejszym artykule uwage poświęcimy tylko wybranym zagadnieniom. Konieczne tu „skompresowanie” narracji dokonane zostało dzięki trzem rozwiązaniom. Po pierwsze, korzystając z faktu, że w tomie tym znalazły się także poświęcone standardom życia opracowania innych autorów, zrezygnowaliśmy ze szczegółowego omawiania problemów już poruszonych przez nich. Po drugie, nie dążymy do szerokiego zreferowania istniejącej literatury przedmiotu czy przedstawienia wszystkich kierunków badawczych - naszym celem jest przede wszystkim scharakteryzowanie podstawowych założeń studiów nad standardami życia i najważniejszych wykorzystywanych metod, bez porywania się na ich encyklopedyczny opis. Po trzecie wreszcie, uwagę naszą skupiliśmy na badaniach standardów życia, niemal całkowicie pomijając studia dotyczące tzw. jakości życia. Decyzja taka nie oznacza, że nie uznajemy tego kierunku za ważny i wart opisania. Sądzimy jednak, że nurt ten jako charakteryzujacy się większym zróżnicowaniem perspektyw i metod badawczych wymagałby oddzielnego, pogłębionego studium.

${ }^{6}$ Siłę takiej perspektywy dostrzec można wyraźnie w pracach jednego z najważniejszych jej przedstawicieli: E.P. Thompsona, The Making of the English Working Class, Londyn 1963; tenże, Time, work-discipline and industrial capitalism, „Past and Present" 38, 1967, no. 1, s. 56-97.

7 Nie jest to jednak reguła, wskazać tu można chociażby na studia dotyczące budżetów czasu czy dzieci pochodzących z klas niższych, por. H.-J. Voht, Time and Work in England 1750-1830, Oxford 2000; J. Humphries, Childhood and Child Labour in the British Industrial Revolution, Cambridge 2010. 


\section{Wskaźniki standardu życia - założenia podstawowe}

Czytelnik prac dotyczących standardów życia szybko dostrzeże, że kwestią dla ich wartości najistotniejszą jest wykorzystanie adekwatnych wskaźników warunków życia ludności. Wskaźniki takie spełniać muszą kilka podstawowych kryteriów. Należą do nich przede wszystkim: powiązanie wykorzystywanej miary z badanym zjawiskiem, jej kwantytatywność, możliwość wyliczenia dla wielu populacji i przedziałów czasowych. Im pełniej dany wskaźnik spełnia te wymogi, tym bardziej wiarygodne będą wnioski wyciagane na jego podstawie. Poul Thestrup, autor jednego z pionierskich opracowań na temat standardów życia w Kopenhadze w latach 1730-1800, powołał się na definicje sformułowane przez ekspertów Organizacji Narodów Zjednoczonych, wskazujących na 12 czynników, które powinny być brane pod uwagę. $\mathrm{Na}$ liście tej znalazły się: 1) zdrowie, w tym warunki demograficzne, 2) żywność i dieta, 3) edukacja, w tym umiejętność pisania i czytania, 4) warunki pracy, 5) poziom zatrudnienia, 6) konsumpcja i oszczędności, 7) transport, 8) warunki mieszkaniowe, w tym wyposażenie mieszkań, 9) odzież, 10) rekreacja i rozrywki, 11) bezpieczeństwo socjalne, 12) prawa człowieka. Jednocześnie autor ten od razu zaznaczył, że w przypadku historycznych mieszkańców stolicy Danii ze względu na zasób źródeł i możliwości opracowania skupi się tylko na trzech najważniejszych komponentach: wyżywieniu i diecie, płacach realnych oraz zdrowiu 8 .

W dotychczasowej praktyce badawczej do analizy standardów życia wykorzystywano najczęściej: dietę, PKB per capita, wynagrodzenia realne, strukturę dochodów, długość i masę ciała, wybrane wskaźniki demograficzne (np. trwanie życia, umieralność noworodków, niemowląt i dzieci, tempo przyrostu populacji) ${ }^{9}$. Od końca XX w. coraz częściej zaczęto się skupiać nad HDI (Human Development Index), czyli syntetycznym mierniku rozwoju społecznego (ludzkiego), na który składa się: oczekiwana długość życia noworodka (e0), poziom edukacji (mierzony liczbą lat edukacji, które mają przed sobą pięcioletnie dzieci rozpoczynające proces kształcenia lub liczbą lat edukacji, które mają za soba osoby w wieku 25 lat), dochód krajowy brutto na jednego mieszkańca mierzony parytetem siły nabywczej.

${ }^{8}$ P. Thestrup, The Standard of Living in Copenhagen 1730-1800. Some Methods of Measurement, København 1971, s. 12.

${ }^{9}$ M. López-Alonso, Measuring Up. A History of Living Standards in Mexico 1850-1950, Stanford 2012, s. 62-66. 
Wszystkie te wskaźniki mają dobre uzasadnienie teoretyczne, a badacze korzystający z nich mogą powoływać się na bogatą literaturę przedmiotu. Każdy z nich daje też możliwość dokonywania porównań w czasie i przestrzeni. Szczególnie dobrze nadają się do tego dane dotyczące wymiarów ciała ludzkiego, które - dzięki pracom archeologów dostępne są nawet dla populacji prehistorycznych ${ }^{10}$. Dużą zaletą wskaźników demograficznych i antropometrycznych jest też fakt, iż mierza one sposób, w jaki dostępne zasoby przekładaja się na rzeczywiste warunki życia ludności ${ }^{11}$. Z kolei siłą miar wywodzących się z ekonomii jest ich powszechna dostępność w odniesieniu do nowoczesnych społeczeństw, pozwalająca na dokonywanie złożonych analiz biorących pod uwagę m.in. różnice między państwami, regionami, wyznaniami, klasami i warstwami społecznymi, płciami, kohortami wiekowymi. $\mathrm{Z}$ większą precyzją wychwytuja też one szybko następujące zmiany, skoro mogą być wyliczane $\mathrm{z}$ dokładnością do bardzo krótkich odcinków czasu.

Niestety, każdy z tych wskaźników obciążony jest pewnymi wadami. Miary opisujące sytuację ekonomiczną moga okazać się niezbyt przydatne do analizy populacji utrzymujacych się przede wszystkim z rolnictwa, w znacznym stopniu autarkicznych i funkcjonujących poza rynkiem. Jeśli przeważająca część ludności nie otrzymuje wynagrodzenia lub dostępne dane dotyczą tylko wybranych sektorów gospodarki, wskaźniki takie okazać się mogą bardzo zawodne. W związku z tym większość analiz historycznych wykorzystujących miary tego typu skupia się na ostatnich stuleciach, stosunkowo rzadko podejmując problematykę wcześniejszych epok. W przypadku średniowiecza czy początków epoki nowożytnej wykorzystanie opracowanych na potrzeby czasów nam współczesnych metod musi odbywać się z wielką ostrożnością ${ }^{12}$. Trzeba też pamiętać, że jeśli dane społeczeństwo charakteryzuje się znacznym zróżnicowaniem majątkowym, gdzie obok licznych biedaków istnieje też nieliczna, ale bardzo bogata elita, uzyskane dla niego średnie wartości mogą w niewielkim tylko stopniu odnosić się warunków życia większej części populacji. Z kolei próba porównywania

${ }^{10}$ R.H. Steckel, What can be learned from skeletons that might interest economists, historians, and other social scientists?, „American Economic Review” 93, 2003, nr 2, s. 213-220.

${ }^{11}$ M. López-Alonso, dz. cyt., s. 66.

12 Zastrzeżenie takie dotyczy zresztą również badaczy czasów późniejszych. Analizy poświęcone Irlandii sprzed tzw. wielkiego głodu, opierające się m.in. na wynagrodzeniach, wskazały na ograniczoną użyteczność tego wskaźnika, por. J. Mokyr, C.Ó. Gráda, Poor and getting poorer? Living standards in Ireland before the Famine, EHR, t. 41, 1988, nr 2, s. 209-235. 
wskaźników między punktami odległymi w czasie lub przestrzeni musi uwzględniać kwestię różnic w strukturze konsumpcji wynikających z odmiennych warunków życia danych społeczności. Za przykład posłużyć tu może fakt, iż w budżetach domowych mieszkańców północnej Europy wydatki na opał stanowiły znacznie istotniejszą pozycję niż to miało miejsce np. w odniesieniu do Indii ${ }^{13}$.

Wskaźniki antropometryczne zaś nazbyt często mogą być wyliczone jedynie w odniesieniu do mężczyzn, których wzrost mierzony był przez komisje poborowe. W konsekwencji nie pozawalają one $\mathrm{z}$ reguły na analizę sytuacji kobiet, subpopulacji nieobjętych obowiązkiem służby wojskowej, dzieci. Badacze sięgający do materiałów innego pochodzenia, jak choćby wyników prac archeologów czy dokumentów wytwarzanych na potrzeby szkół i wymiaru sprawiedliwości, spotykają się natomiast często z zarzutem niereprezentatywności zgromadzonej podstawy źródłowej.

\section{Konsumpcja żywności}

Jednym z pierwszych zagadnień analizowanych przez historyków zainteresowanych wskaźnikami życia była konsumpcja żywności. Impuls do podjęcia badań wyszedł w $1961 \mathrm{r}$. od redakcji „Annales. Économies, Sociétés, Civilisations”, na łamach których Fernand Braudel opublikował biuletyn pt. Vie matérielle et comportements biologiques wraz ze specjalną ankieta mająca na celu zbadanie warunków życia materialnego od późnego średniowiecza po wiek XX ${ }^{14}$. Miała ona posłużyć stworzeniu uniwersalnego standardu badań nad konsumpcja, ale ostatecznie jej wyniki zostały wykorzystane najszerzej w fundamentalnym dziele tego wybitnego francuskiego historyka ${ }^{15}$. Posłużyła też oczywiście za wzór wielu studiom monograficznym związanym z dziejami gospodarczymi poszczególnych miast, regionów czy państw. W powstających od początku lat sześćdziesiątych ubiegłego wieku pracach nie chodziło jedynie o rekonstrukcję diety ludzi pochodzących z różnych grup społecznych, ale szersze zdiagnozowanie rozwoju gospodarczego.

${ }_{13}$ P. Malanima, Energy crisis and growth 1650-1850: the European deviation in a comparative perspective, „Journal of Global History” 1, 2006, nr 1, s. 101-121.

${ }^{14}$ F. Braudel, Vie matérielle et comportements biologiques, „Annales. Économies, Sociétés, Civilisations" 16, 1961, nr 3, s. 545-549.

${ }^{15} \mathrm{~F}$. Braudel, Civilisation matérielle et capitalisme (XVe-XVIII e siècle), t. 1, Paris 1967; polskie wydanie: tenże, Kultura materialna, gospodarka i kapitalizm XV-XVIII wieku, t. 1: Struktury codzienności, przeł. M. Ochab i P. Graff, Warszawa 1992, s. 93-222. 
Prace wychodziły więc poza tradycyjny opis kultury kulinarnej elity społecznej, miały charakter kwantytatywny i dotyczyły „zwykłych ludzi”. Osiagnięte rezultaty $\mathrm{w}$ kontekście międzynarodowym zostały zebrane i opisane przez Bartolome'a Bennassara i Josepha Goya w 1975 r. ${ }^{16}$

Dostępność źródeł rachunkowych pozwoliła na wzorowane na francuskich badania sięgające średniowiecza, a uzyskane serie danych zostały wykorzystane w analizie takich zjawisk, jak kryzys gospodarczy tej epoki. Doskonałych przykładów takich opracowań dostarczają badania Christophera Dyera, który tezę o wzroście standardu życia chłopów w późnośredniowiecznej Anglii udowodnił m.in. poprzez analizę ewolucji wyżywienia pracowników zatrudnianych do prac polowych w czasie żniw przez folwarki. Angielski uczony zaobserwował, że w okresie po czarnej śmierci udział mięsa i piwa wśród źródeł kalorii stopniowo rósł, a chleb tracił na znaczeniu ${ }^{17}$.

W duchu badań francuskich i pod wpływem inspiracji „Annales”, biorący udział w braudelowskiej ankiecie Andrzej Wyczański ${ }^{18}$ napisał książkę Studia nad konsumpcja żywności w Polsce $w$ XVI $i$ pierwszej połowie XVII $w \cdot{ }^{19}$ Miała ona zupełnie innych charakter niż wcześniejsza praca Marii Dembińskiej, skupiającej się na aspektach kulturowych oraz technicznych ${ }^{20}$, i stanowiła pretekst do całościowego zdiagnozowania produkcji gospodarczej kraju. Wyczański na podstawie zachowanych rachunków zanalizował dzienne racje żywnościowe przedstawicieli różnych grup społecznych oraz skonstruował modele typowego wyżywienia. W porównaniu z chłopami angielskimi dieta polskich robotników rolnych w XVI i na początku XVII stulecia była znacznie uboższa w mięso i ryby, a produkty zbożowe (chleb i piwo) stanowiły zdecydowanie najważniejsze źródło kalorii ${ }^{21}$. Wiele lat później przemiany w zakresie chłopskiego wyżywienia w Królestwie Polskim w kluczowym dla wzrostu standardu życia okresie

${ }_{16}$ B. Bennessar, J. Goy, Contribution à l'histoire de la consommation alimentaire $d u X I V^{e}$ au XIXe siècle, „Annales. Économies, Sociétés, Civilisations” 30, 1975, nr 2, s. $402-430$.

${ }^{17} \mathrm{C}$. Dyer, Changes in diet in the late middle ages: the case of harvest workers, „Agricutural History Review” 36, 1988, s. 21-37; tenże, Standards of Living in the Later Middle Ages. Social Change in England c. 1200-1520, Cambridge 1989, s. 151-160.

18 A. Wyczański, La consommation alimentaire en Pologne au XVI siècle, „Annales. Économies, Sociétés, Civilisations" 17, 1962, nr 2, s. 318-323.

19 A. Wyczański, Studia nad konsumpcja żywności $w$ Polsce $w$ XVI i pierwszej połowie XVII w., Warszawa 1969.

${ }^{20}$ M. Dembińska, Konsumpcja żywnościowa w Polsce średniowiecznej, WrocławWarszawa-Kraków 1963.

${ }^{21}$ A. Wyczański, Studia nad konsumpcja..., s. 103-110. 
drugiej połowy XIX i początków XX w. opisał Tadeusz Sobczak, który pokazał, że w tym czasie możliwe stało się pełne pokrycie zapotrzebowania żywnościowego ludności wiejskiej ${ }^{22}$. Niestety, dziś w polskiej historiografii większą wagę przywiazuje się do badań nad konsumpcją luksusowa lub do odkrywania dawnych przepisów kulinarnych i trudno nie zgodzić się ze zdaniem Jacka Kochanowicza, że więcej wiemy o wzorcach konsumpcji elity społecznej niż standardzie życia większości społeczeństwa ${ }^{23}$.

\section{PKB per capita i place realne}

Studia nad konsumpcją żywności stanowiły punkt wyjścia do obserwacji dawnych społeczeństw przez pryzmat jeszcze innych czynników ekonomicznych mierzacych standard życia. Wyczański zdecydował się bowiem na oszacowanie dochodu narodowego Polski ok. 1580 r. ${ }^{24}$, co było podejściem nowatorskim na skalę europejska. Podstawa jego obliczeń była konsumpcja, której typowa wielkość została pomnożona przez liczbę ludności (wiejskiej i miejskiej), a następnie przeliczona w cenach gdańskich. Nie była to jednak jedyna tego typu próba w polskiej historiografii. Wcześniej podobne obliczenia na podstawie źródeł skarbowych i szacunków dochodowości gospodarstw wiejskich podejmował Tadeusz Korzon $^{25}$, a zwłaszcza Witold Kula, którego jednak w polemice z Janem Rutkowskim bardziej interesowały kwestie podziału dochodu społecznego ${ }^{26}$. Z kolei Jerzy Topolski, opierając się na wielkości konsumpcji dwóch produktów-symptomów: zboża i żelaza (stali), zaproponował swoją koncepcję budowy wskaźnika wzrostu gospodarczego umożliwiającego obserwację trendu na przestrzeni tysiąca lat ${ }^{27}$. Niedawno, korzystając

${ }^{22}$ T. Sobczak, Konsumpcja żywnościowa chłopska $w$ Królestwie Polskim $w 2$ połowie XIX $i$ w poczatkach XX wieku, Wrocław 1986.

${ }^{23} \mathrm{~J}$. Kochanowicz, Consumption in the preidustrial and industrial period: a comment on research. Problems and approaches, APH, t. 102, 2010, s. 89-100.

${ }^{24}$ A. Wyczański, Studia nad konsumpcja..., s. 182-213.

25 T. Korzon, Wewnętrzne dzieje Polski za Stanisława Augusta (1764-1795), t. 1-6, wyd. 2: Kraków-Warszawa 1897, t. 2, s. 412-424.

${ }^{26}$ W. Kula, Podziat dochodu społecznego, w: Historia, zacofanie, rozwój, Warszawa 1983, s. 11-21; tenże, Teoria ekonomiczna ustroju feudalnego, Warszawa 1983, s. 8-17; tenże, Rozwój gospodarczy Polski XVI-XVIII w., Warszawa 1993; tenże, Dochód społeczny ziem polskich $w$ XVIII w, RDSG, t. 66, 2006, s. 137-151; J. Rutkowski, Badania nad podziatem dochodów w Polsce nowożytnej, t. 1, Kraków 1938.

${ }_{27}$ J. Topolski, Wskaźniki wzrostu gospodarczego Polski od X do XX wieku, KH, t. 74,1967 , nr 4 , s. $995-1012$. 
z udoskonalanej w ciagu ostatnich lat metodologii, obliczenia PKB per capita dla Polski wykonali Mikołaj Malinowski i Jan Luiten van Zandena ${ }^{28}$. Umieścili oni swoje badania $\mathrm{w}$ szerszej debacie dotyczacej małej i dużej dywergencji. Pod jej wpływem podjęto się szacunków historycznego PKB Anglii ${ }^{29}$, Holandii ${ }^{30}$, Włoch ${ }^{31}$ i Hiszpanii ${ }^{32}$.

Dla wielu miast europejskich i azjatyckich przeprowadzono też badanie płac realnych pracowników najemnych. Współcześnie analizy tego zagadnienia wykorzystują metodę opracowaną przez Roberta Allena ${ }^{33}$, ale wywodzą się z jednej strony z badań nad konsumpcja, z drugiej zaś - z prób rekonstrukcji budżetów domowych różnych grup społecznych. W nauce polskiej tradycja tych ostatnich sięga XIX w. oraz Franciszka Bujaka i Tadeusza Korzona ${ }^{34}$. Zarówno u nas ${ }^{35}$, jak i w historiografii światowej zwykle podejmowali je historycy gospodarki wiejskiej ${ }^{36}$.

${ }_{28}$ Zob. artykuł Mikołaja Malinowskiego w niniejszym tomie.

${ }^{29}$ S. Broadberry, S. Campbell, A. Klein, M. Overton, B. Van Leeuwen, British Economic Growth, 1270-1870, Cambridge 2015.

${ }^{30}$ J.L. Van Zanden, B. Van Leeuwen. Persistent but not consistent: The growth of national income in Holland 1347-1807, EEH, t. 49, 2012, nr 2, s. 119-130; S. Broadberry, S. Campbell, A. Klein, M. Overton, B. Van Leeuwen, dz. cyt.

${ }^{31} \mathrm{P}$. Malanima, The long decline of a leading economy: GDP in Central and Northern Italy, 1300-1913, EREH, t. 15, 2010, s. 169-219.

32 C. Álvarez-Nogal, L. Prados de la Escosura, The rise and fall of Spain (12701850), EHR, t. 66, 2013, nr 1, s. 1-37.

${ }^{33}$ R. Allen, The great divergence in European wages and prices from the Middle Ages to the First World War, EEH, t. 38, 2001, nr 4, s. 411-447.

${ }^{34}$ F. Bujak, Budzet chtopa, „Ekonomista” 2, 1903, s. 169-199; T. Korzon, dz. cyt., t. 2, s. 104 (budżet szlachcica w mieście w 2. poł. XVIII w.).

${ }_{35}$ M.in.: A. Wyczański, Gospodarka wiejska w Polsce XIV wieku w ujęciu liczbowym, RDSG, t. 62, 2002, s. 167-187; tenże, Czy chłopu było źle w Polsce XVI wieku?, KH, t. 85, 1978, nr 3, s. 627-641; tenże, Próba analizy matematycznej ekonomii gospodarstwa chtopskiego $w$ Polsce XVI-XVIII w., „Studia z Dziejów Gospodarstwa Wiejskiego", Warszawa 1966, t. 8, s. 341-344; tenże, Wieś polskiego odrodzenia, Warszawa 1969, s. 151-152; A. Wawrzyńczyk, Gospodarstwo chtopskie na Mazowszu w XVI i na poczatku XVII w., Warszawa 1962, s. 185-192; L. Żytkowicz, Studia nad wydajnościa gospodarstwa wiejskiego na Mazowszu w XVII wieku, Warszawa 1969, s. 76-84; P. Guzowski, Chłopi i pieniqdze na przełomie średniowiecza $i$ czasów nowożytnych, Kraków 2008, s. 108-135. Przykład analizy budżetu gospodarstwa miejskiego można znaleźć w artykule: J. Wójtowicz, Dziennik tkacza toruńskiego Johanna Gottlieba Kadacha - źródto wiedzy o Toruniu z przełomu XVIII i XIX wieku, „Zapiski Historyczne" 59, 1994, z. 4, s. 89-105.

${ }^{36}$ G. Bois, The Crisis of Feudalism. Economy and Society in Eastern Normandy c. 1300-1550, Cambridge 1984, s. 149-155; P. Bowden, Agricultural prices, farm profits and rents, 1500-1640, w: Chapters from Agrarian History of England and Wales 1500-1750, red. J. Thirsk, t. 1, Cambridge 1990, s. 71-83; H. Kitsikopoulos, The impact of the Black Death on peasant economy in England 1350-1500, „Journal of 
Wydaje się, że moga one stanowić wzór badań grup społecznych dotychczas traktowanych w studiach nad standardami życia marginalnie, tzn. chłopów - właścicieli gospodarstw rolno-hodowlanych. Skupienie się historiografii na pracownikach najemnych (głównie miejskich) jako grupie, której rola stopniowo rosła w najbardziej rozwiniętych gospodarkach Europy nie powinno wiązać się z ignorowaniem standardów życia ludności wiejskiej, stanowiącej większość społeczeństw późnośredniowiecznych i wczesnonowożytnych ${ }^{37}$.

\section{Biologiczny standard życia}

W poszukiwaniu innych niż ekonomiczne sposobów analizy standardów życia współcześni zachodnioeuropejscy i amerykańscy badacze powiązali kwestie żywnościowe z biologicznymi i demograficznymi. Pozytywne zmiany w dostępie i konsumpcji żywności skojarzono ze wzrostem fizycznym i wskaźnikiem waga/wzrost (BMI). I w tej dziedzinie za prekursorów można uznać historyków francuskich, którzy zwrócili uwagę na dziwiętnastowieczne dane antropometryczne poborowych znajdujące się w archiwach wojskowych ${ }^{38}$. Przełomem była jednak amerykańska dyskusja o standardzie życia niewolników zapoczątkowana książką Roberta W. Fogela i Stanleya Engermana ${ }^{39}$. Od tamtej pory ukazały się fundamentalne opracowania Johna Komlosa ${ }^{40}$ i Richarda Steckela ${ }^{41}$, i dziś jest to jedna z najpopularniejszych wśród

Peasant Studies" 29, 2002, s. 71-90; tenże, Standards of living and capital formation in re-plague England: a peasant budget model, EHR, t. 53, 2000, s. 237-261.

${ }^{37}$ Więcej na ten temat pisze w niniejszym tomie Mikołaj Malinowski.

${ }^{38}$ E. Le Roy Ladurie, N. Bernageau, Y. Pasquet, Le conscrit et l'ordinateur. Perspectives de recherche sur les archives militaires du XIX ${ }^{e}$ siècle français, „Studi Storici” 10, 1969, s. 260-308; E. Le Roy Ladurie, N. Bernageau, Etude sur un contingent militaire (1868). mobilité géographique, délinquance et stature, mises en rapport avec d'autres aspects de la situation des conscrits, „Annales de Démographie Historique”, 1971, s. 311-337.

${ }^{39}$ R.W. Fogel, S. Engerman, Time on the Cross: The Economics of Negro Slavery, vols. 1-2, Boston 1974. Wybór najważniejszych stanowisk zob.: U genezy konfliktu etnicznego. Głosy $w$ dyskusji o niewolnictwie $w$ Amerykach, wyd. J. Kochanowicz, M. Kula, Kraków 1980.

${ }^{40}$ J. Komlos, Nutrition and Economic Development in the Eighteenth-Century Habsburg Monarchy: An Anthropometric History, Pincetown 1989.

${ }^{41}$ R.H. Steckel, Slave height profiles from coastwise manifests, EEH, t. 16, 1979, $\mathrm{nr}$ 4, s. 363-380; tenże, Stature and standard of living, „Journal of Economic Literature" 33, 1995, nr 4, s. 1903-1940; tenże, Heights and human welfare: recent developments and new directions, EEH, t. 46, 2009, nr 1, s. 1-23. 
historyków i ekonomistów metod badań standardów życia ludzi różnych kontynentów, systemów politycznych, społecznych i ekonomicznych ostatnich dwustu lat ${ }^{42}$. Na ich znaczenie wskazywano od dawna w literaturze polskiej w kontekście opisu New economic history ${ }^{43}$, ale na szersza skalę do polskiej historiografii badania nad biologicznym standardem zostały wprowadzone przez Michała Kopczyńskiego ${ }^{44}$. Według niego poprawa standardu wyżywienia od schyłku lat sześćdziesiątych XIX w. „umożliwiła realizację uśpionego dotąd potencjału genetycznego przede wszystkim uboższej części ludności” ${ }^{45}$.

\section{Demografia}

Współcześnie uważa się, że podnoszenie się biologicznych standardów życia w najbardziej rozwiniętych regionach świata od drugiej połowy XIX w. związane było przede wszystkim z pozytywnymi zmianami w zakresie odżywiania. Wcześniej jako bardzo ważny powód dodawano również postęp w opiece medycznej. Ta druga kwestia miała większe znaczenie w kontekście wskaźników demograficznych.

Badacze standardów życia zwracają szczególna uwagę na dwa parametry demograficzne. Pierwszy z nich to oczekiwana długość życia w momencie narodzin (e0). Możliwość uzyskania danych historycznych na ten temat związana jest z pojawieniem się dokumentacji metrykalnej w XVI w. i rozwojem demograficznej metody rekonstrukcji rodzin. Dysponujemy więc obliczeniami dla okresu nowożytnego, choć w literaturze mamy próby ustalenia oczekiwanej długości życia w wieku lat 18, 20 czy 25 także dla późnego średniowiecza ${ }^{46}$. Punktem odniesienia sa zazwyczaj dane angielskie uzyskane przez zespół Cambridge Group for the History of Population and Social Structures ${ }^{47}$, kilkakrotnie

${ }^{42}$ R. Floud, R.W. Fogel, B. Harris, S.C. Hong, The Changing Body. Health, Nutrition, and Human Development in the Western World since 1700, Cambridge 2011; więcej na ten temat pisze w niniejszym tomie Michał Kopczyński.

${ }_{43}$ J. Pomorski, Paradygmat „New economic history”. Studium z teorii rozwoju nauki historycznej, Lublin 1985.

${ }^{44}$ M. Kopczyński, Wielka transformacja. Badania nad uwarstwieniem społecznym $i$ standardem życia $w$ Królestwie Polskim 1866-1913 w świetle pomiarów antropometrycznych poborowych, Warszawa 2006.

45 Tamże, s. 190.

46 J. Hatcher, A.J. Piper, D. Stone, Monastic mortality: Durham Priory, 1395-1529, EHR, t. 59, 2006, nr 4, s. 667-687.

47 E.A. Wrigley, R.S. Schofield, The Population History of England 15411871: A Reconstruction, Cambridge 1981; E.A. Wrigley, R.S. Davies, J.E. Oeppen, 
zestawiane $\mathrm{z}$ danymi $\mathrm{z}$ innych krajów, także w perspektywie europejsko-azjatyckiej ${ }^{48}$. Dzięki temu można potwierdzić dla okresu przynajmniej od drugiej połowy XVIII w. trend wzrostu standardu życia. Niestety, polskie badania dotyczące oczekiwanej długości trwania życia w czasach historycznych wyglądają ubogo. Jedyna, sięgająca przełomu XVIII i XIX w. tablicę wymieralności przygotował Edmund Piasecki w monografii ludności wsi Bejsce ${ }^{49}$, a dla XIX w. dane wielkopolskie i śląskie opracował Mieczysław Kędelskino.

Tylko nieco lepiej wygląda dorobek polskiej historiografii dotyczący tematyki związanej z umieralnością noworodków (dzieci, które nie osiągnęły wieku czterech tygodni) oraz niemowląt (do 1 roku życia). Kwestia ta stanowi ważny problem z zakresu światowej demografii historycznej, a ograniczenie umieralności w najmłodszych kohortach wiekowych dowodzi postępu cywilizacyjnego i wzrostu standardu życia. Wzorcem w tym zakresie jest Szwecja, w której dzięki wczesnemu (już od XVIII w.) kształceniu specjalistycznemu lekarzy i akuszerek oraz zaangażowaniu w podstawową edukację medyczną pastorów, popularyzację karmienia piersią i odpowiednich publikacji, najwcześniej widoczne były ślady zmniejszenia się skali zjawiska ${ }^{51}$. Zmiany sa również korelowane z rozwojem gospodarczym ${ }^{52}$, miejscem zamieszkania (miasto/

R.S. Schofield, English Population History from Family Reconstitution 1580-1837, Cambridge 1997.

${ }^{48}$ R.W. Fogel, The Escape from Hunger and Premature Death, 1700-2100. Europe, America, and the Third World, Cambridge 2004, s. 2; P.T. Hoffman, D.S. Jacks, P.A. Levin, P.H. Lindert, Sketching the rise of real inequality in Early Modern Europe, w: Living Standards in the Past. New Perspectives on Well-Being in Asia and Europe, eds. R.C. Allen, T. Bengtsson, M. Dribe, Oxford 2005, s. 133-138.

${ }^{49}$ E. Piasecki, Próba sporzadzenia okresowych tablic życia na podstawie ksiag ruchu naturalnego $w$ XVIII-XX w., „Przeszłość Demograficzna Polski” 16, 1985, s. 139-151; tenże, Ludność parafii bejskiej (woj. kieleckie) w świetle ksiag metrykalnych z XVIII-XX w. Studium demograficzne, Wrocław-Warszawa 1990, s. 281-304.

${ }^{50}$ M. Kędelski, Umieralność i trwanie życia w Wielkopolsce w latach 1816-1875, „Przeszłość Demograficzna Polski” 16, 1985, s. 109-138; tenże, Umieralność i trwanie życia ludności Wielkopolski w XIX wieku, Poznań 1996; tenże, Piramida wieku $i$ tablice trwania życia ludności Ślaska w 1864 r., „Przeszłość Demograficzna Polski” 20, 1997, s. 49-71.

${ }^{51}$ A. Bränstrom, Historical decline of infant mortality in Sweden 1750-1950. Past and present research into its decline, w: The Decline of Infant Mortality in Europe 1800-1950. Four National Case Studies, eds. C.A. Corsini. P.P. Viazzo, Florence 1993, s. 21.

${ }^{52}$ P. Huck, Infant mortality and living standards of English workers during the Industrial Revolution, JEH, t. 55, 1995, nr 3, s. 528-550; J. Schellekens, Economic change and infant mortality in England 1580-1837, „Journal of Interdisciplinary History" 32, 2001, nr 1, s. 1-13. 
wieśs $)^{53}$, dostępem do wody ${ }^{54}$, grupa społeczna ${ }^{55}$, wyznaniem ${ }^{56}$ czy ubezpieczeniem chorobowym ${ }^{57}$. Dzięki tym badaniom możemy stwierdzić, że w przeciwieństwie do okresu wcześniejszego, kiedy największe szanse na dożycie wieku dorosłego miały dzieci z rodzin najbogatszych ${ }^{58}$, w ostatnich dekadach XIX w. ograniczenie umieralności niemowląt i noworodków stało się powszechne we wszystkich grupach społecznych. Jak dotąd polska demografia historyczna nie doczekała się syntetycznego ujęcia problemu, ale na podstawie studiów nad poszczególnymi regionami (głównie Ślaskiem) czy miastami możemy stwierdzić, że ziemie polskie dzieliły z pozostałymi krajami Europy trendy demograficzne i wysoka umieralność noworodków i niemowląt zarówno w miastach ${ }^{59}$, jak i na wsi $^{60}$ utrzymywała się niemal do końca XIX w.

${ }^{53}$ N. Williams, C. Galley, Urban-rural differentials in infant mortality in Victorian England, „Population Studies” 49, 1995, nr 3, s. 401-420; C. Galley, N. Shelton, Bridging the gap: Determining long-term changes in infant mortality in pre-registration England And Wales, „Population Studies” 55, 2001, nr 1, s. 65-77.

${ }^{54}$ G. Macassa, A. Ponce de Leon, B. Burström, The impact of water supply and sanitation on area differentials in the decline of diarrhoeal disease mortality among infants in Stockholm 1878-1925, ,ScandinavianJournal ofPublic Health” 34, 2006, nr 5, s. 526-533.

${ }_{55}$ M.R. Haines, Socioeconomic differentials in infant and child mortality during mortality decline: England and Wales, 1890-1911, „Population Studies” 49, 1995, nr 2, s. 297-315; S. Scott, C.J. Duncan, Interacting effects of nutrition and social class differentials on fertility and infant mortality in pre-industrial population, „Population Studies" 54, 2000, nr 1, s. 71-87.

56 J.H. Wolleswinkel-van den Bosch, F. van Poppel, C. Looman, J. Mackenbach, Determinants of infant and early childhood mortality levels and their decline in the Netherlands in the late nineteenth century, „International Journal of Epidemiology” 29, 2000, nr 6, s. 1031-1040; F. van Poppel, M. Jonker, K. Mandemakers, Differential infant and child mortality in three Dutch regions, 1812-1909, EHR, t. 58, 2005, nr 2, s. 272-309.

${ }^{57}$ J.R. Bowblis, The decline in infant death rates, 1878-1913. The role of early sickness insurance programs, JEH, t. 70, 2010, nr 1, s. 221-232.

${ }^{58}$ Z. Razi, Life, Marriage and Death in a Medieval Parish: Economy, Society and Demography in Halesowen, 1270-1400, Cambridge 1980; J.-P. Bardet, Ruen aux XVII et XVIII siècles. Les mutations d'un espace social, t. 1, Paris 1983, s. 370; J. Landers, Death and the Metropolis: Studiesinthe Demographic HistoryofLondon, 1670-1830, Cambridge 1993, s. 186-188; S. Beauvalet-Boutouyrie, La démographie de l'époque moderne, Paris 1999, s. 261; G. Clark, G. Hamilton, Survival of the richest: The Maltusian mechanism in pre-industrial England, „Journal of Economic History” 66, 2006, nr 3, s. 707-736.

${ }^{59}$ C. Kuklo, Rodzina w osiemnastowiecznej Warszawie, Białystok 1991, s. 164; M. Kędelski, Rozwój demograficzny Poznania $w$ XVIII i na poczqtku XIX wieku, Poznań 1992, s. 145; G. Liczbińska, Umieralność i jej uwarunkowania wśród katolickiej i ewangelickiej ludności historycznego Poznania, Poznań 2009, s. 49; taż, Infant and child mortality among Catholics and Lutherans in nineteenth-century Poznań, „Journal of Biosocial Science” 41, 2009, nr 5, s. 661-683.

${ }^{60}$ M. Górny, Ruch naturalny ludności Tarnowskich Gór w latach 1801-1870, „Studia i Materiały z Dziejów Ślaska” 13, 1983, s. 56; E. Piasecki, Ludność..., s. 117-128.; 
Oprócz oczekiwanej długości trwania życia w momencie narodzin i umieralności noworodków i niemowląt badacze standardów życia zwracaja uwage na inne parametry demograficzne, takie jak ograniczenie płodności czy umieralności osób dorosłych, których zróżnicowanie w czasie może stanowić przyczynę lub konsekwencje zmian standardów życia ${ }^{61}$.

\section{Nierówności ekonomiczne}

Zainteresowanie badaczy standardów życia problemem nierówności majątkowych ${ }^{62}$ wynika $\mathrm{z}$ dwóch źródeł. Po pierwsze, kwestia ta ma duże znaczenie dla analiz produkcji lub wynagrodzeń. Historyk chcący przeliczyć globalne wartości PKB lub zbliżonych wskaźników na głowę mieszkańca powinien bowiem wziąc pod uwagę problem koncentracji własności. W przypadku społeczeństw charakteryzujących się dużymi dysproporcjami majątkowymi może się okazać, że proste podzielenie całej sumy dochodów lub dóbr przez liczbę mieszkańców daje wyniki nieopisujace ani rzeczywistej sytuacji członków elit, ani też warunków życia osób zajmujacych dolne pozycje w hierarchii społecznej. Choć nierówności ekonomiczne moga być w jakimś stopniu łagodzone przez rozbudowany system instytucji charytatywnych, różnorodne mechanizmy redystrybucji dóbr i wsparcia potrzebujących, to z całą pewnościa nie można ignorować ich znaczenia. Na zainteresowanie takim aspektem nierówności istotny wpływ mają też debaty dotyczące dysproporcji

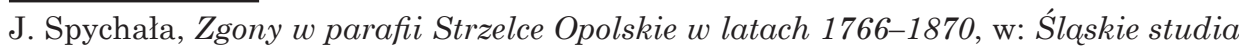
demograficzne, t. 3: Zgony, red. Z. Kwaśny, Wrocław 1996 (Acta Universitatis Wratislaviensis 1825, Historia CXXV), s. 7-26; D. Daszkiewicz-Ordyłowska, Zgony w parafii toszeckiej w latach 1789-1877, w: Ślaskie studia demograficzne..., t. 3, s. 27-43; K. Górna, Narodziny, śluby i zgony na Górnym Ślasku w XVIII wieku, w: Wesela, chrzciny $i$ pogrzeby $w$ XVI-XVIII wieku. Kultura życia $i$ śmierci, red. H. Suchojad, Warszawa 2001, s. 33-42.

${ }^{61}$ R. Boucekkine, D. de la Croix, O. Licandro, Early mortality declines at the dawn of modern growth, „Scandinavian Journal of Economics” 105, 2003, nr 3, s. 401-418; Life Under Pressure: Mortality and Living Standards in Europe and Asia, 1700-1900, eds. T. Bengtsson et al., Cambridge 2004; M. Kelly, C.Ó Gráda, Living standards and mortality since the Middle Ages, EHR, t. 67, 2014, nr 2, s. 358-381.

${ }^{62}$ Co oczywiste, kwestia zróżnicowania standardów życia między grupami społecznymi i regionami podejmowana jest także często $\mathrm{w}$ studiach dotyczących wymiarów ciała, długości życia czy wynagrodzeń. Specyfika badań przedstawionych w tej sekcji polega więc przede wszystkim na uczynieniu z nierówności tematu podstawowego, a nie na samym dostrzeżeniu tego zagadnienia niejako przy okazji innych analiz. 
majątkowych obserwowanych we współczesnych społeczeństwach ${ }^{63}$. Źródło drugie wiąże się natomiast z tradycją wywodząca się z badań Simona Kuznetsa, który analizował nierówności ekonomiczne w kontekście rozwoju ekonomicznego. Tak zwana krzywa Kuznetsa opisuje proces, w którym wczesne fazy industrializacji wiązać się maja z powiększaniem się dysproporcji majątkowych między elitami korzystającymi z nowych możliwości inwestycyjnych a resztą społeczeństwa. Dopiero z czasem, m.in. w wyniku spowolnienia przyrostu populacji, demokratyzacji oraz związkom zawodowym tendencja taka ulega zahamowaniu i nierówności się zmniejszaja ${ }^{64}$. Choć analizy Kuznetsa opisywały zmiany zachodzące w wyniku rewolucji przemysłowej, współcześni historycy gospodarczy coraz chętniej sięgają po nie w pracach dotyczących wcześniejszych okresów. Za Van Zandenem postuluja oni istnienie tzw. superkrzywej Kuznetsa, która miałaby opisywać procesy akumulacji majątkowej zachodzącej w niektórych regionach już w epoce wczesnonowożytnej. Według takich interpretacji znaczne zróżnicowanie majątkowe obserwowane na przykład w holenderskich miastach w XVI-XVII w. uznać należy za dowód na znaczną aktywność ekonomiczna zamieszkujących je populacji i wskaźnik rozwoju gospodarczego ${ }^{65}$.

Z przedstawionych powyżej dwóch przyczyn zainteresowania nierównościami wynikaja pewne różnice w metodach i źródłach wykorzystywanych przez poszczególnych badaczy. Historycy nawiązujący do koncepcji Kuznetsa okazują się tu być zdecydowanie bardziej kwantytatywni. Podstawę ich studiów stanowią najczęściej źródła masowe wytworzone do celów podatkowych. Oszacowania majątków lub kwoty wpłacane przez poszczególnych podatników zostaja poddane analizie przy pomocy różnorodnych metod statystycznych. Obok najczęściej w tym celu wykorzystywanego współczynnika Giniego i percentyli coraz chętniej sięga się też po różnorodne miary oparte na entropii, dokonuje się ich dekompozycji, porównuje między sobą wybrane grupy społeczne lub bada zmiany w czasie ${ }^{66}$. Z kolei historycy zainteresowani

${ }_{63}$ T. Piketty, Kapitał $w$ XXI wieku, tłum. A. Bilik, Warszawa 2015.

${ }^{64} \mathrm{~S}$. Kuznets, Economic growth and income inequality, „American Economic Review" 45, 1955, nr 1, s. 1-28.

65 J.L. van Zanden, Tracing the beginning of the Kuznets curve: Western Europe during the early modern period, EHR, t. 48, 1995, nr 4, s. 643-664 (DOI: 10.2307/2598128).

${ }^{66}$ R.H. Steckel, C.M. Moehling, Rising inequality: Trends in the distribution of wealth in industrializing New England, JEH, t. 61, 2001, nr 1, s. 160-183; G. Alfani, Wealth inequalities and population dynamics in early modern northern Italy, 
społecznymi konsekwencjami nierówności są nieco bliżsi nurtowi studiów nad jakością życia, a w swych analizach więcej uwagi poświęcaja takim kwestiom, jak dostęp do edukacji ${ }^{67}$ czy czas pracy $^{68}$. Poszerzenie zestawu pytań badawczych skutkuje też większym zróżnicowaniem podstawy źródłowej.

W polskiej historiografii trudno na razie wskazać na studia poświęcone nierównościom ekonomicznym analizowanym w kontekście standardów życia. Prace z zakresu socjotopografii ${ }^{69}$ lub stratyfikacji szlachty ${ }^{70}$ zawieraja wprawdzie sporo interesujacych informacji dotyczących zróżnicowania majątkowego, ale sposób ich prezentacji oraz zastosowane techniki analityczne służą tu innym celom i nie pozwalaja na ich proste powiąanie $\mathrm{z}$ badaniami standardu życia. Można mieć jednak nadzieję, że w najbliższych latach pojawią się studia podejmujące omawiane tu zagadnienie.

\section{Alfabetyzacja i numeracy}

Przyczyny, dla których badacze standardów życia interesują się problemem poziomu wykształcenia historycznych populacji są całkiem oczywiste. Wystarczy przypomnieć, że edukacja stanowi w nowoczesnych społeczeństwach jeden z podstawowych predyktorów dochodów, a pośrednio wpływa też na wiele innych zjawisk, w tym choćby przewidywaną długość życia ${ }^{71}$. Trudno więc dziwić się uwzględnieniu tego zagadnienia $\mathrm{w}$ projektach badawczych dotyczących standardów życia w przeszłości. W praktyce jednak przedsięwzięcie takie napotyka na wiele trudności. Wskaźniki opisujące stopień objęcia populacji edukacja szkolna, najchętniej wykorzystywane w analizach dotyczących współczesności, mają ograniczoną przydatność w przypadku

„Journal of Interdisciplinary History” 40, 2010, nr 4, s. 513-549 (DOI: 10.1162/ jinh.2010.40.4.513).

${ }^{67}$ E. Frankema, Has Latin America always been unequal? A comparative study of asset and income inequality in the long twentieth century, Leiden 2009.

${ }^{68}$ L.D. Schwarz, Custom, wages and workload in England during industrialization, „Past and Present” 197, 2007, s. 143-175.

69 J. Wiesiołowski, Socjotopografia późnośredniowiecznego Poznania, Poznań 1982; K. Mikulski, Przestrzeń i społeczeństwo Torunia od końca XIV do poczatku XVIII wieku, Torun 1999.

70 A. Wyczański, Uwarstwienie społeczne w Polsce XVIwieku. Studia, Wrocław 1977.

${ }^{71}$ E.R. Meara, S. Richards, D.M. Cutler, The gap gets bigger: Changes in mortality and life expectancy, by education, 1981-2000, „Health Affairs” 27, 2008, nr 2, s. $350-360$. 
badań historycznych. Znaczna część dawnych społeczeństw, w tym zwłaszcza kobiety, formalną edukacją nie była objęta, zaś istniejące systemy szkolnictwa zapewniały bardzo zróżnicowany i trudny do porównywania poziom nauczania. Co więcej, nawet wprowadzenie obowiązku szkolnego nie musiało gwarantować realizacji tego zarzadzenia ${ }^{72}$. Wobec takich trudności historycy chcacy analizować poziom wykształcenia dawnych społeczeństw sięgaja zazwyczaj po dane dotyczące alfabetyzacji lub umiejętności liczenia (numeracy).

Spośród tych dwóch wskaźników dłuższą tradycję badawczą mają z cała pewnością studia nad piśmiennością. Analizy dotyczące podpisów składanych przy okazji różnorodnych czynności administracyjnych lub deklarowania umiejętności pisania w spisach dostępne są dla wielu okresów i obszarów ${ }^{73}$, w tym także ziem polskich ${ }^{74}$. Choć nie zawsze dokonuje się ich do opisu standardów życia, dostarczają one danych, które łatwo można w tym celu wykorzystać ${ }^{75}$. Równocześnie trzeba też jednak podkreślić, że przed badaniami nad piśmiennością wciąż stoja poważne wyzwania. Wbrew pozorom najważniejsza nie jest konieczność poszerzenia bazy źródłowej, ale raczej udzielenie odpowiedzi na pytania postawione przez Harveya Graffa i innych badaczy społecznych aspektów piśmienności. Prowadzone przez nich analizy podważyły prosty podział na analfabetów/piszących, zwracając uwagę na istnienie wielu stanów pośrednich (tylko czytający, znający niektóre litery, mieszkający $\mathrm{z}$ osobą piśmienną itp.) oraz podały $\mathrm{w}$ wątpliwość przekonanie o bezwzględnej opłacalności edukacji ${ }^{76}$. Nawet w dziewiętnastowiecznej

${ }^{72}$ Y.N. Soysal, D. Strang, Construction of the first mass education systems in nineteenth-century Europe, „Sociology of Education” 62, 1989, nr 4, s. 277-288.

${ }^{73}$ L. Stone, Literacy and education in England, 1640-1900, „Past and Present” 42, 1969, s. 69-139; R. Schofield, The measurement of literacy in pre-industrial England, w: Literacy in Traditional Societies, red. J. Goody, Cambridge 1975, s. 310-325; D. Cressy, Literacy and the Social Order: Reading and Writing in Tudor and Stuart England, Cambridge 1980; H.J. Graff, The Legacies of Literacy: Continuities and Contradictions in Western Culture and Society, Bloomington 1987; R.A. Houston, Literacy in Early Modern Europe: Culture and Education, 1500-1800, Harlow 1988; S.T. Nalle, Literacy and culture in early modern Castille, „Past and Present” 125, 1989, s. 65-96.

${ }^{74}$ A. Wyczański, Oświata a pozycja społeczna w Polsce XVI stulecia. Próba oceny umiejętności pisania szlachty województwa krakowskiego $w$ drugiej połowie XVI w., w: Społeczeństwo staropolskie, t. 1, red. A. Wyczański, Warszawa 1976, s. 27-55; W. Urban, Sztuka pisania w województwie krakowskim w XVII i XVIII wieku, „Przegląd Historyczny" 75, 1984, z. 1, s. 38-82.

75 J. Reis, Economic growth, human capital formation and consumption in Western Europe before 1800, w: Living Standards in the Past..., s. 195-225.

${ }^{76}$ H.J. Graff, The Literacy Myth. Cultural Integration and Social Structure in the Nineteenth Century, New York 1979. 
Ameryce brak wykształcenia nie musiał przekreślać szans na odniesienie sukcesu, zaś ekonomiczna kalkulacja mogła sprawiać, że rodziny często wolały czerpać korzyści z pracy dzieci niż je edukować ${ }^{77}$.

Wydaje się, że badania nad umiejętnością liczenia po części unikają pułapek stojących przed analizami piśmienności. Kompetencje matematyczne (a zwłaszcza arytmetyczne) niewatpliwie przekładaja się w aktywność ekonomiczna i o ile wyobrazić sobie można analfabetę jako kupca lub rzemieślnika, to trudno sądzić, że działalność taka prowadziłby z sukcesem ktoś niezaznajomiony z liczbami. Wobec tego badania dotyczące stopnia umiejętności liczenia (zazwyczaj określanej mianem numeracy) w dawnych populacjach dobrze wpisują się w studia nad edukacja, kapitałem ludzkim i standardem życia. Niestety, jak z pewną ironią zauważyła Patricia Cline Cohen, umiejętność liczenia jest bardzo słabo policzalna ${ }^{78}$, choć podejmowano próby jej sprawdzenia także w polskiej historiografii ${ }^{79}$. Trudno w tej kwestii jednak o jednoznaczne wskaźniki oraz proste odróżnienie dostępnego każdemu użytkownikowi języka poziomu podstawowego od kompetencji bardziej zaawansowanych ${ }^{80}$. Stajac przed takimi wyzwaniami, badacze standardów życia najchętniej sięgaja po techniki analityczne wykorzystujące tzw. skupienia wieku. Zjawisko takie, dobrze znane historykom wykorzystującym w swej pracy naukowej różnorodne spisy ludności, polega na zaokraglaniu wieku przez członków tradycyjnych społeczności. Wiele osób pytanych o liczbę przeżytych lat, zamiast podawać dokładne wartości, poprzestawało na zadeklarowaniu wieku przybliżonego, zazwyczaj kończącego się na cyfrze 0 lub 5. Praktykę taka, od dawna irytująca demografów, uznać można za wskaźnik zaznajomienia z liczbą. Osoby niewykorzystujące arytmetyki w życiu codziennym i w konsekwencji słabo liczace nie znały swojego dokładnego wieku i nie przywiązywały do niego wagi ${ }^{81}$. Z kolei spadek występowania zaokragleń wieku wskazuje na wzrost kompetencji matematycznych w populacji, pojawienie się instytucji (przede wszystkim państwowych, ale też gospodarczych

${ }_{77}$ S. Ogilvie, A.W. Carus, Institutions and economic growth in historical perspective, w: Handbook of Economic Growth, eds. P. Aghion, S.N. Durlaf, t. 2, Oxford 2014, s. 462 .

78 P.C. Cohen, A Calculating People. The Spread of Numeracy in Early America, Chicago 1982, s. 6-12.

79 A. Wyczański, Próba oceny umiejętności liczenia małopolskiej komisji lustracyjnej 1564-1565, „Odrodzenie i Reformacja w Polsce” 50, 2006, s. 61-73.

80 R.J. Emigh, Numeracy or enumeration? The uses of numbers by states and societies, „Social Science History” 26, 2002 , nr 4, s. 654.

${ }^{81}$ B. A'Hearn, J. Baten, D. Crayen, Quantifying quantitative literacy. Age heaping and the history of human capital, JEH, t. 68, 2009, nr 3, s. 783-808. 
i religijnych) wymuszających korzystanie z arytmetyki w życiu codziennym. Zdaniem badaczy kapitału ludzkiego wzrost numeracy powiązany też jest z rozwojem gospodarczym i poprawą warunków życia ${ }^{82}$.

Współczesne zainteresowanie numeracy analizowanym w kontekście standardów życia, związane przede wszystkim z pracami Jörga Batena i naukowców z nim współpracujących, zaowocowało też studiami obejmujacymi ziemie polskie. Wskazać tu należy przede wszystkim na dotyczące XIX stulecia studia Batena i Mikołaja Szołtyska ${ }^{83}$ oraz Batena i Ralpha Hippego ${ }^{84}$. Numeracy w wybranych populacjach z XVIII w. badał Mikołaj Szołtysek ${ }^{85}$. Wciąż jednak trudno uznać problem kompetencji matematycznych ludności zamieszkującej ziemie polskie za wyczerpany.

\section{Podsumowanie}

Zaprezentowany przez nas przegląd badań i problemów związanych ze standardami życia w przeszłości jest rodzajem wprowadzenia w tematykę i jednoczesna próbą inspiracji polskich badaczy do podjęcia studiów w tej dziedzinie ${ }^{86}$. Co prawda już podręcznik Witolda Kuli Problemy i metody historii gospodarczej sprzed ponad półwieku wyliczał konieczność zanalizowania szeregu zagadnień, które dziśs wchodzą w zakres badań nad standardami życia (konsumpcja, produkt krajowy, trwanie życia) ${ }^{87}$, a nawet opisał najlepsze ówcześnie stosowane metody, to problematyka ta była podejmowana niewspółmiernie rzadko w stosunku do znaczenia. Wskazuje na to też zainteresowanie, jaką cieszyło się kolokwium „Od społeczeństwa tradycyjnego do społeczeństwa nowoczesnego. Przemiany społeczno-gospodarcze na tle standardów i jakości życia” zorganizowane przez Cezarego Kuklę i Dariusza Chojeckiego

${ }^{82}$ D. Crayen, J. Baten, Global trends in numeracy 1820-1949 and its implications for long-term growth, EEH, t. 47, 2010, nr 1, s. 82-99.

${ }^{83}$ J. Baten, M. Szołtysek, A golden age before serfdom? The human capital of Central-Eastern and Eastern Europe in the 17th-19th centuries, „MPIDR Working Papers" WP-2014-008.

${ }^{84}$ R. Hippe, J. Baten, Regional inequality in human capital formation in Europe, 1790-1880, „Scandinavian Economic History Review” 60, 2012, nr 3, s. 254-289 (http://dx.doi.org/10.1080/03585522.2012.727763).

${ }_{85}$ M. Szołtysek, Rethinking East-Central Europe. Family Systems and Co-residence in Polish-Lithuanian Commonwealth, t. 1-2, Bern 2015, t. 1, s. 856.

${ }^{86}$ Najświeższy międzynarodowy przegląd badań można znaleźć w pracy: A History of the Global Economy from 1500 to the Present, red. J. Baten, Cambridge 2016.

87 W. Kula, Problemy i metody historii gospodarczej, Warszawa 1963. 
w czasie XIX Powszechnego Zjazdu Historyków Polskich w Szczecinie w 2014 r. Dyskusje, jakie miały wówczas miejsce historiografii polskiej dowodza potrzeby podjęcia systematycznych i wszechstronnych badań, prowadzonych zgodnie ze standardami wypracowanymi w nauce światowej i na forum międzynarodowym prezentowanych choćby na wzór rosyjski ${ }^{8}$. Zbyt często powstaja w Polsce prace, których wartość w kontekście prezentowanych tu badań jest bez watpienia wysoka, ale nie funkcjonuja one zupełnie $\mathrm{w}$ nauce światowej ${ }^{89}$. Warto też tworzyć zespoły badawcze łaczące nie tylko historyków różnych dziedzin, ale również ekonomistów, demografów czy antropologów. Wydaje się, że bez podjęcia takich przedsięwzięć wiele ważnych dla polskiej historiografii debat wciąż pozostać może nierozstrzygniętych lub sprowadzonych do poziomu dyskusji prowadzonej z pozycji bardziej ideologicznych niż naukowych. Za przykład posłużyć tu moga ponownie zyskujące na znaczeniu polemiki dotyczące społecznych skutków sytemu pańszczyźnianego czy konsekwencji rozbiorów. Analizy standardów życia mogłyby wiele wnieść do takich dyskusji.

\section{Bibliografia}

A'Hearn B., Baten J., Crayen D., Quantifying quantitative literacy. Age heaping and the history of human capital, „Journal of Economic History” 68, 2009, nr 3, s. 783-808.

Alfani G., Wealth inequalities and population dynamics in early modern northern Italy, „Journal of Interdisciplinary History” 40, 2010, nr 4, s. $513-549$.

Allen R., The Great Divergence in European wages and prices from the Middle Ages to the First World War, „Explorations in Economic History” 38, 2001, nr 4, s. 411-447.

Álvarez-Nogal C., Prados de la Escosura L., The rise and fall of Spain (12701850), „Economic History Review” 66, 2013, nr 1, s. 1-37.

Bardet J.P., Ruen aux XVII et XVIII e siècles. Les mutations d'un espace social, t. 1, Paris 1983.

Baten J., Szołtysek M., A golden age before serfdom? The human capital of Central-Eastern and Eastern Europe in the 17th-19th centuries, „MPIDR Working Papers" WP-2014-008.

Beauvalet-Boutouyrie S., La démographie de l'époque moderne, Paris-Berlin 1999.

88 B. Mironov, The Standard of Living and Revolutions in Russia, 1700-1917, red. G.L. Freeze, London-New York 2012.

${ }^{89}$ Czego dobrym przykładem jest monumentalne dzieło W. Stysia, Wspótzależność rozwoju rodziny chtopskiej $i$ jej gospodarstwa, Wrocław 1959. 
Bengtsson T., Living Standards and Economic Stress, w: Life Under Pressure: Mortality and Living Standards in Europe and Asia, 1700-1900, red. T. Bengtsson et al., Cambridge 2004, s. 27-59.

Bennessar B., Goy J., Contribution à l'histoire de la consommation alimentaire du XIV e au XIX eiècle, „Annales. Économies, Sociétés, Civilisations” 30, 1975, nr 2, s. 402-430.

Bois G., The Crisis of Feudalism. Economy and Society in Eastern Normandy c. 1300-1550, Cambridge 1984.

Boucekkine R., de la Croix D., Licandro O., Early mortality declines at the dawn of modern growth, „Scandinavian Journal of Economics” 105, 2003, nr 3, s. 401-418.

Bowblis J.R., The decline in infant death rates, 1878-1913. The role of early sickness insurance programs, „Journal of Economic History” 70, 2010, nr 1, s. 221-232.

Bowden, P. Agricultural prices, farm profits and rents, 1500-1640, w: Chapters from Agrarian History of England and Wales 1500-1750, ed. J. Thirsk, t. 1, Cambridge 1990, s. 71-83.

Bränstrom A., Historical decline of infant mortality in Sweden 1750-1950. Past and present research into its decline, w: The Decline of Infant Mortality in Europe 1800-1950. Four National Case Studies, eds. C.A. Corsini, P.P. Viazzo, Florence 1993, s. 19-34.

Braudel F., Civilisation matérielle et capitalisme (XVe-XVIII e siècle), t. 1, Paris 1967.

Braudel F., Kultura materialna, gospodarka $i$ kapitalizm XV-XVIII wieku, t. 1: Struktury codzienności, przeł. M. Ochab, P. Graff, Warszawa 1992.

Braudel F., Vie matérielle et comportements biologiques „Annales. Économies, Sociétés, Civilisations" 16, 1961, nr 3, s. 545-549.

Broadberry S., Campbell B.M.S., Klein A., Overton M., van Leeuwen B., British Economic Growth, 1270-1870, Cambridge 2015.

Bujak F., Budzet chtopa, „Ekonomista” 2, 1903, s. 169-199.

Clark G., Hamilton G., Survival of the richest: The Malthusian mechanism in pre-industrial England, „Journal of Economic History” 66, 2006, nr 3, s. 707-736.

Cohen M.N., Health and the Rise of Civilization, New Haven 1989.

Cohen P.C., A Calculating People. The Spread of Numeracy in Early America, Chicago 1982.

Crayen D., Baten J., Global trends in numeracy 1820-1949 and its implications for long-term growth, „Explorations in Economic History” 47, 2010, nr 1, s. 82-99.

Cressy D., Literacy and the Social Order: Reading and Writing in Tudor and Stuart England, Cambridge 1980.

Daszkiewicz-Ordyłowska D., Zgony w parafii toszeckiej w latach 1789-1877, w: Ślaskie studia demograficzne, t. 3: Zgony, red. Z. Kwaśny, Wrocław 1996 (Acta Universitatis Wratislaviensis 1825, Historia CXXV), s. 27-43.

Dembińska M., Konsumpcja żywnościowa w Polsce średniowiecznej, WrocławWarszawa-Kraków 1963. 
Dyer C., Changes in diet in the late middle ages: the case of harvest workers, „Agricutural History Review” 36, 1988, s. 21-37.

Dyer C., Standards of Living in the Later Middle Ages. Social Change in England c. 1200-1520, Cambridge 1989.

Emigh R.J., Numeracy or Enumeration? The Uses of Numbers by States and Societies, „Social Science History” 26, 2002, nr 4, s. 653-698.

Engels F., Położenie klasy robotniczej w Anglii, tłum. A. Długosz, Warszawa 1952.

Filtzer D.A., The hazards of urban life in late Stalinist Russia. Health, hygiene, and living standards 1943-1953, Cambridge 2010.

Floud R., Fogel R.W, Harris B., Hong S.C., The Changing Body. Health, Nutrition, and Human Development in the Western World since 1700, Cambridge 2011.

Fogel R. W., The Escape from Hunger and Premature Death, 1700-2100. Europe, America, and the Third World., Cambridge 2004.

Fogel R.W., Engerman S., Time on the Cross: The Economics of Negro Slavery, t. 1-2, Boston 1974.

Frankema E., Has Latin America always Been Unequal? A Comparative Study of Asset and Income Inequality in the Long Twentieth Century, Leiden 2009.

Galley C., Shelton N., Bridging the gap: Determining long-term changes in infant mortality in pre-registration England and Wales, „Population Studies" 55, 2001, nr 1, s. 65-77.

Górna K., Narodziny, śluby i zgony na Górnym Ślasku w XVIII wieku, w: Wesela, chrzciny $i$ pogrzeby $w$ XVI-XVIII wieku. Kultura życia i śmierci, red. H. Suchojad, Warszawa 2001, s. 33-42.

Górny M., Ruch naturalny ludności Tarnowskich Gór w latach 1801-1870, „Studia i Materiały z Dziejów Ślaska” 13, 1983, s. 8-86.

Graff H.J., The Legacies of Literacy: Continuities and Contradictions in Western Culture and Society, Bloomington 1987.

Graff H.J., The Literacy Myth. Cultural Integration and Social Structure in the Nineteenth Century, New York 1979.

Guzowski P., Chłopi i pieniadze na przełomie średniowiecza i czasów nowożytnych, Kraków 2008.

Haines M. R., Socioeconomic differentials in infant and child mortality during mortality decline: England and Wales, 1890-1911, „Populationa Studies” 49, 1995, nr 2, s. 297-315.

Hatcher J., Piper A.J., Stone D., Monastic mortality: Durham Priory, 13951529, „Economic History Review” 59, 2006, nr 4, s. 667-687.

Hippe R., Baten J., Regional inequality in human capital formation in Europe, 1790-1880, „Scandinavian Economic History Review” 60, 2012, nr 3, s. $254-289$.

A History of the Global Economy from 1500 to the Present, ed. J. Baten, Cambridge 2016.

Hoffman P.T., Jacks D.S., Levin P. A., Lindert P.H., Sketching the rise of real inequality in early modern Europe, w: Living Standards in the Past. New Perspectives on Well-Being in Asia and Europe, eds. R. Allen, T. Bengtsson, M. Dribe, Oxford 2005, s. 133-138. 
Houston R.A., Literacy in early Modern Europe: culture and education, 15001800, Harlow 1988.

Huck P., Infant mortality and living standards of English workers during the Industrial Revolution, „Journal of Economic History” 55, 1995, nr 3, s. $528-550$.

Humphries J., Childhood and Child Labour in the British Industrial Revolution, Cambridge 2010.

Kelly M., Ó Gráda C., Living standards and mortality since the Middle Ages, „Economic History Review” 67, 2014, nr 2, s. 358-381.

Kędelski M., Piramida wieku i tablice trwania życia ludności Ślaska w 1864 r., „Przeszłość Demograficzna Polski” 20, 1997, s. 49-71.

Kędelski M., Rozwój demograficzny Poznania w XVIII i na poczqttu XIX wieku, Poznań 1992,

Kędelski M., Umieralność i trwanie życia ludności Wielkopolski w XIX wieku, Poznań 1996.

Kędelski M., Umieralność i trwanie życia w Wielkopolsce w latach 1816-1875, „Przeszłość Demograficzna Polski” 16, 1985, s. 109-138.

Kitsikopoulos H., Standards of living and capital formation in pre-plague England: A peasant budget model, „Economic History Review” 53, 2000, s. 237-261.

Kitsikopoulos H., The impact of the Black Death on peasant economy in England 1350-1500, „Journal of Peasant Studies” 29, 2002, s. 71-90.

Kochanowicz J., Consumption in the preidustrial and industrial period: a comment on research. Problems and approaches, „Acta Poloniae Historica” 102, 2010, s. 89-100.

Komlos J., Nutrition and Economic Development in the Eighteenth-Century Habsburg Monarchy: An Anthropometric History, Pincetown 1989.

Kopczyński M., Wielka transformacja. Badania nad uwarstwieniem spotecznym $i$ standardem życia $w$ Królestwie Polskim 1866-1913 w świetle pomiarów antropometrycznych poborowych, Warszawa 2006.

Korzon T., Wewnętrzne dzieje Polski za Stanistawa Augusta (1764-1795), wyd. 2, t. 1-2, Kraków-Warszawa 1897.

Kuklo C., Rodzina w osiemnastowiecznej Warszawie, Białystok 1991.

Kula W., Dochód spoteczny ziem polskich w XVIII w, „Roczniki Dziejów Społecznych i Gospodarczych" 66, 2006, s. 137-151.

Kula W., Podziat dochodu społecznego, w: Historia, zacofanie, rozwój, Warszawa 1983, s. 11-21.

Kula W., Problemy i metody historii gospodarczej, Warszawa 1963.

Kula W., Rozwój gospodarczy Polski XVI-XVIII w., Warszawa 1993.

Kula W., Teoria ekonomiczna ustroju feudalnego, Warszawa 1983.

Kuznets S., Economic growth and income inequality, „American Economic Review" 45, 1955, nr 1, s. 1-28.

Landers J., Death and the Metropolis: Studies in the Demographic History of London, 1670-1830, Cambridge 1993.

Le Roy Ladurie E., Bernageau N., Étude sur un contingent militaire (1868). Mobilité géographique, délinquance et stature, mises en rapport avec 
d'autres aspects de la situation des conscrits, „Annales de Démographie Historique", 1971, s. 311-337.

Le Roy Ladurie E., Bernageau N., Pasquet Y., Le conscrit et l'ordinateur. Perspectives de recherche sur les archives militaires du XIX ${ }^{e}$ siècle français, „Studi Storici” 10, 1969, s. 260-308.

Liczbińska G., Infant and child mortality among Catholics and Lutherans in nineteenth-century Poznań, „Journal of Biosocial Science” 41, 2009, nr 5, s. $661-683$.

Liczbińska G., Umieralność $i$ jej uwarunkowania wśród katolickiej $i$ ewangelickiej ludności historycznego Poznania, Poznań 2009.

Life Under Pressure: Mortality and Living Standards in Europe and Asia, 1700-1900, eds. T. Bengtsson et al., Cambridge 2004.

Literacy in Traditional Societes, ed. J. Goody, Cambridge 1975.

Living Standards in the Past. New Perspectives on Well-Being in Asia and Europe, eds. R. Allen, T. Bengtsson, M. Dribe, Oxford 2005.

López-Alonso M., Measuring Up. A History of Living Standards in Mexico 1850-1950, Stanford 2012.

Macassa G., Ponce de Leon A., Burström B., The impact of water supply and sanitation on area differentials in the decline of diarrhoeal disease mortality among infants in Stockholm 1878-1925, „Scandinavian Journal of Public Health" 34, 2006, nr 5, s. 526-533.

Malanima P., Energy crisis and growth 1650-1850: the European deviation in a comparative perspective, ,Journal of Global History” 1, 2006, nr 1, s. 101-121.

Malanima P., The long decline of a leading economy: GDP in Central and Northern Italy, 1300-1913, „European Review of Economic History” 15, 2010, s. 169-219.

Meara E.R., Richards S., Cutler D.M., The gap gets bigger: Changes in mortality and life expectancy, by education, 1981-2000, „Health Affairs” 27, 2008, nr 2, s. 350-360.

Mikulski K., Przestrzeń i społeczeństwo Torunia od końca XIV do poczatku XVIII wieku, Toruń 1999.

Mironov B., The Standard of Living and revolutions in Russia, 1700-1917, ed. G.L. Freeze, London-New York 2012.

Mokyr J., Ó Gráda C., Poor and getting poorer? Living standards in Ireland before the Famine, „Economic History Review” 41, 1988, nr 2, s. 209-235.

Nalle S.T., Literacy and culture in early modern Castille, „Past and Present” 125,1989 , s. $65-96$.

Ogilvie S., Carus A.W., Institutions and economic growth in historical perspective, w: Handbook of Economic Growth, eds. P. Aghion, S.N. Durlaf, t. 2, Oxford 2014, s. 403-513.

Pamuk S., van Zanden J.L., Standards of living, w: The Cambridge Economic History of Modern Europe, eds. S. Broadberry, K.H. O’Rourke, t. 1, Cambridge 2010, s. 217-234.

Piasecki E., Ludność parafii bejskiej (woj. kieleckie) w świetle ksiag metrykalnych z XVIII-XX w. Studium demograficzne, Wrocław-Warszawa 1990. 
Piasecki E., Próba sporzadzenia okresowych tablic życia na podstawie ksiag ruchu naturalnego $w$ XVIII-XX $w$, „Przeszłość Demograficzna Polski” 16, 1985, s. 139-151.

Piketty T., Kapitat $w$ XXI wieku, tłum. A. Bilik, Warszawa 2015.

Pomorski J., Paradygmat „New economic history”. Studium z teorii rozwoju nauki historycznej, Lublin 1985.

Razi Z., Life, Marriage and Death in a Medieval Parish: Economy, Society and Demography in Halesowen, 1270-1400, Cambridge 1980.

Reis J., Economic growth, human capital formation and consumption in Western Europe before 1800, w: Living Standards in the Past. New Perspectives on Well-Being in Asia and Europe, eds. R.C. Allen, T. Bengtsson, M. Dribe, Oxford 2005, s. 195-225.

Rutkowski J., Badania nad podziałem dochodów w Polsce nowożytnej, t. 1, Kraków 1938.

Schellekens J., Economic Change and Infant Mortality in England 1580-1837, „Journal of Interdisciplinary History” 32, 2001, nr 1, s. 1-13.

Schofield R., The measurement of literacy in pre-industrial England, w: Literacy in Traditional Societes, ed. J. Goody, Cambridge 1975, s. 310-325.

Schwarz L.D., Custom, Wages and workload in England during industrialization, „Past and Present” 197, 2007, s. 143-175.

Scott S., Duncan C.J., Interacting effects of nutrition and social class differentials on fertility and infant mortality in pre-industrial population, „Population Studies" 54, 2000, nr 1, s. 71-87.

Sen A., The Standard of Living. The Tanner Lectures on Human Values, Clare Hall, Cambridge, 1985, ed. G. Hawthorn, Cambridge 1987.

Sobczak T., Konsumpcja żywnościowa chtopska w Królestwie Polskim w 2 połowie XIX $i$ w poczatkach XX wieku, Wrocław 1986.

Soysal Y.N., Strang D., Construction of the first mass education systems in nineteenth-century Europe, „Sociology of Education” 62, 1989, nr 4, s. 277288.

Spychała J., Zgony w parafii Strzelce Opolskie w latach 1766-1870, w: Ślaskie studia demograficzne, t. 3: Zgony, red. Z. Kwaśny, Wrocław 1996 (Acta Universitatis Wratislaviensis 1825, Historia CXXV), s. 7-26.

Steckel R.H., Moehling C.M., Rising Inequality: Trends in the distribution of wealth in industrializing New England, „Journal of Economic History” 61, 2001, nr 1, s. 160-183.

Steckel R.H., Heights and human welfare: Recent developments and new directions, „Explorations in Economic History” 46, 2009, nr 1, s. 1-23.

Steckel R.H., Slave height profiles from coastwise manifests, „Explorations in Economic History" 16, 1979, nr 4, s. 363-380.

Steckel R.H., Stature and standard of living, „Journal of Economic Literature” 33, 1995, nr 4, s. 1903-1940.

Steckel R.H., What can be learned from skeletons that might interest economists, historians, and other social scientists?, „American Economic Review” 93, 2003, nr 2, s. 213-220. 
Stone L., Literacy and education in England, 1640-1900, „Past and Present" 42, 1969, s. 69-139.

Styś W., Współzależność rozwoju rodziny chłopskiej i jej gospodarstwa, Wrocław 1959.

Szołtysek M., Rethinking East-Central Europe. Family Systems and Co-Residence in Polish-Lithuanian Commonwealth, t. 1-2, Bern 2015.

The Decline of Infant Mortality in Europe 1800-1950. Four National Case Studies, eds. C.A. Corsini. P.P. Viazzo, Florence 1993.

Thestrup P., The Standard of Living in Copenhagen 1730-1800. Some Methods Of Measurement, København 1971.

Thompson E.P., The Making of the English Working Class, London 1963.

Thompson E.P., Time, work-discipline and industrial capitalism, „Past and Present" 38, 1967, s. 56-97.

Topolski J., Wskaźniki wzrostu gospodarczego Polski od X do XX wieku, „Kwartalnik Historyczny” 74, 1967, nr 4, s. 995-1012.

U genezy konfliktu etnicznego. Głosy $w$ dyskusji o niewolnictwie w Amerykach, wyd. J. Kochanowicz, M. Kula, Kraków 1980.

Urban W., Sztuka pisania w województwie krakowskim w XVII i XVIII wieku, „Przegląd Historyczny” 75, 1984, z. 1, s. 38-82.

Van Poppel F., Jonker M., Mandemakers K., Differentials infant and child mortality in three Dutch regions, 1812-1909, „Economic History Review” 58, 2005, nr 2, s. 272-309.

VanZandenJ.L., Tracing the beginning of the Kuznetscurve: Western Europe during the early modern period, „Economic History Review” 48, 1995, nr 4, s. 643-664.

Van Zanden J.L., Van Leeuwen B., Persistent but not consistent: The growth of national income in Holland 1347-1807, „Explorations in Economic History" 49, 2012, nr 2, s. 119-130.

Voht H.-J., Time and Work in England 1750-1830, Oxford 2000.

Wawrzyńczyk A., Gospodarstwo chłopskie na Mazowszu w XVI i na poczatku XVII w., Warszawa 1962.

Wiesiołowski J., Socjotopografia późnośredniowiecznego Poznania, Poznań 1982.

Williams N., Galley C., Urban-rural differentials in infant mortality in Victorian England, „Population Studies” 49, 1995, nr 3, s. 401-420.

Wolleswinkel-van den Bosch J.H., Van Poppel F., Looman C., Mackenbach J., Determinants of infant and early childhood mortality levels and their decline in the Netherlands in the late nineteenth century, „International Journal of Epidemiology" 29, 2000, nr 6, s. 1031-1040.

Wójtowicz J., Dziennik tkacza toruńskiego Johanna Gottlieba Kadacha źródto wiedzy o Toruniu z przełomu XVIII i XIX wieku, „Zapiski Historyczne" 59, 1994, z. 4, s. 89-105.

Wrigley E.A., Schofield R.S., The Population History of England 1541-1871: A Reconstruction, Cambridge 1981.

Wrigley E.A., Davies R.S., Oeppen J.E., Schofield R.S., English Population History from Family Reconstitution 1580-1837, Cambridge 1997. 
Wyczański A., Czy chłopu było źle w Polsce XVI wieku?, „Kwartalnik Historyczny" 85, 1978, nr 3, s. 627-641.

Wyczański A., Gospodarka wiejska w Polsce XIV wieku w ujęciu liczbowym, „Roczniki Dziejów Społecznych i Gospodarczych” 62, 2002, s. 167-187.

Wyczański A., La consommation alimentaire en Pologne au XVI siècle, „Annales. Économies, Sociétés, Civilisations” 17, 1962, nr 2, s. 318-323.

Wyczański A., Oświata a pozycja społeczna w Polsce XVI stulecia. Próba oceny umiejętności pisania szlachty województwa krakowskiego $w$ drugiej połowie XVI w., w: Społeczeństwo staropolskie, t. 1, Warszawa 1976, s. $27-55$.

Wyczański A., Próba analizy matematycznej ekonomii gospodarstwa chłopskiego $w$ Polsce XVI-XVIII w., „Studia z Dziejów Gospodarstwa Wiejskiego", t. 8, Warszawa 1966, s. 341-344.

Wyczański A., Próba oceny umiejętności liczenia małopolskiej komisji lustracyjnej 1564-1565, „Odrodzenie i Reformacja w Polsce” 50, 2006, s. 61-73.

Wyczański A., Studia nad konsumpcja żywności w Polsce w XVI i pierwszej potowie XVII w., Warszawa 1969.

Wyczański A., Uwarstwienie społeczne w Polsce XVI wieku. Studia, Wrocław 1977.

Wyczański A., Wieś polskiego odrodzenia, Warszawa 1969.

Żytkowicz L., Studia nad wydajnościa gospodarstwa wiejskiego na Mazowszu w XVII wieku, Warszawa 1969.

Piotr Guzowski

Radosław Poniat

Standards of living and quality of life in international historiography.

Overview of research and problems

(Summary)

The research of standards of living and quality of life has a long history within the field of science. It has been carried out for years not only by historians, but also by economists, demographers, sociologists, physical anthropologists, or social psychologists, in search of the causes of economic growth and, in historical context, of the regions which experienced greatest economic success in subsequent eras, starting from antiquity. The researchers in the field are divided into two groups: those who study the standard of living - the "quantitative" researchers, elaborating certain objective indices on the basis of mass data sources, and "qualitative" researchers, who prefer to base their study on narrative sources. The paper focuses on the former type of sources, among which the most important are food consumption, GDP per capita and real wages, physical height and the weight/height index (BMI), expected life span, newborn and infant mortality rate, literacy and numeracy, and social inequalities. 
Piotr Guzowski - historyk gospodarczy i demograf historyczny, adiunkt w Instytucie Historii i Nauk Politycznych Uniwersytetu w Białymstoku i pracownik Instytutu Historii im. T. Manteuffla Polskiej Akademii Nauk, sekretarz naukowy Centrum Badań Struktur Demograficznych i Gospodarczych Przednowoczesnej Europy Środkowo-Wschodniej Uniwersytetu w Białymstoku; zainteresowania badawcze: przemiany gospodarczo-demograficzne w długiej perspektywie od wczesnego średniowiecza po wiek XIX; autorem m.in. książi: Chłopi i pieniqdze na przełomie średniowiecza i czasów nowożytnych, Kraków 2008. Email: guzowski@uwb.edu.pl.

Radosław Poniat - dr, adiunkt w Instytucie Historii i Nauk Politycznych Uniwersytetu w Białymstoku, pracownik działającego na tym uniwersytecie Centrum Badań Struktur Demograficznych i Gospodarczych Przednowoczesnej Europy Środkowo-Wschodniej; zainteresowania badawcze: demografia historyczna, zastosowanie metod kwantytatywnych w badaniach historycznych, socjologia struktur społecznych; autor książki: Stużba domowa w miastach na ziemiach polskich od połowy XVIII do końca XIX wieku, Warszawa 2014. E-mail: r.poniat@uwb.edu.pl. 